University of Montana

ScholarWorks at University of Montana

\title{
Taxing audit markets and reputation: An examination of the U.S. tax shelter controversy
}

\author{
John Incardona \\ Zayed University \\ Yezen Kannan \\ Duquesne University \\ Ronald Premuroso \\ University of Montana - Missoula \\ Julia L. Higgs \\ Florida Atlantic University \\ Ivy Huang \\ Queens College
}

Follow this and additional works at: https://scholarworks.umt.edu/acct_finance_pubs

Part of the Accounting Commons, and the Finance and Financial Management Commons Let us know how access to this document benefits you.

\section{Recommended Citation}

Incardona, John; Kannan, Yezen; Premuroso, Ronald; Higgs, Julia L.; and Huang, Ivy, "Taxing audit markets and reputation: An examination of the U.S. tax shelter controversy" (2014). Accounting and Finance Faculty Publications. 1.

https://scholarworks.umt.edu/acct_finance_pubs/1

This Article is brought to you for free and open access by the Accounting and Finance at ScholarWorks at University of Montana. It has been accepted for inclusion in Accounting and Finance Faculty Publications by an authorized administrator of ScholarWorks at University of Montana. For more information, please contact scholarworks@mso.umt.edu. 
Taxing Audit Markets and Reputation:

An Examination of the U.S. Tax Shelter Controversy

\author{
John Incardona \\ Zayed University \\ john.incardona@zu.ac.ae
}

Yezen Kannan

Duquesne University

kannany@duq.edu

\author{
Ronald Premuroso* \\ University of Montana \\ School of Business Administration \\ Department of Accounting and Finance \\ 32 Campus Drive \\ Missoula, MT 59812 \\ ronald.premuroso@umontana.edu \\ Tel: (406)-243-6464 \\ Fax: (406)-243-6925 \\ Julia L. Higgs \\ Florida Atlantic University \\ jhiggs@fau.edu \\ Ivy Huang \\ Queens College \\ qianyun.huang@qc.cuny.edu
}

*Corresponding author 


\title{
Taxing Audit Markets and Reputation: An Examination of the U.S. Tax Shelter Controversy
}

\begin{abstract}
From 2002 to 2007, the nation's largest CPA firms faced allegations of illegal activity related to the sale of tax shelters: EY, KPMG and PwC paid fines; KPMG was investigated by a federal grand jury; and EY faced a criminal inquiry. These shelter events occurred shortly after the 2002 collapse of Arthur Andersen, when policy makers were concerned about audit market concentration. This is the first paper to provide a chronological summary of how the tax shelter controversy started and ended. We investigate the stock market reaction to tax shelter news developments between 2003 and 2005 to make inferences about the market's view of audit competition and CPA firm reputation. Our results are consistent with market concern over large audit firm concentration, evidenced by large negative returns for clients of all audit providers upon the KPMG grand jury investigation announcement. We also find that tax shelter activities impact both the reputation of the accounting profession and the individual CPA firms marketing tax shelter products.
\end{abstract}

Keywords:

Aggressive tax shelters, Insurance hypothesis, Auditor reputation, Audit quality 


\section{Taxing Audit Markets and Reputation: An Examination of the U.S. Tax Shelter Controversy}

\section{Introduction}

In November 2003, Congress held hearings on allegedly abusive and/or illegal tax shelters sold by Ernst \& Young, LLP (EY), KPMG, LLP (KPMG) and PricewaterhouseCoopers, LLP (PwC). The accounting profession, as well as these named firms, faced a loss of reputation from information disclosed at these hearings. ${ }^{1}$ KPMG and EY also faced possible criminal indictments or convictions resulting from Department of Treasury and Justice Department (DOJ) investigations, which ultimately could have led to the demise of these firms.

We examine market concerns about the concentration of audit providers. Companies with global operations require an international audit firm for auditor efficiency, reputation, and industry expertise, limiting their choice of auditor. If the reputation of one of the large international audit firms is tarnished such that the firm is either unable to or precluded from providing audit services, publicly-listed global firms on both U.S. and foreign stock markets could be significantly impacted. Therefore, our research should be of interest to academics and practitioners in international jurisdictions.

We use event study methodology to examine whether the market reacted negatively to news large auditors faced criminal investigations during the public announcement of key tax shelter events from 2003 to 2005. Because these investigations could have led to the demise of another large CPA firm, we use market reactions to specific tax shelter public investigation announcements and related public disclosures to make inferences about the potential impact of

\footnotetext{
${ }^{1}$ We investigate publicly available information, including Congressional hearing documents and reports in the financial press. There could have been investigations of other CPA firms which were not made public. The hearing included shelters sold by groups other than CPAs. Our discussion is limited to CPA firms.
} 
concentration in the audit market. We find evidence suggesting the market was concerned with large audit firm market concentration from 2003 to 2005.

We also examine whether sale of tax shelters had a reputational spillover effect, both to the involved audit firms and to the profession as a whole. We address this question by examining cumulative abnormal returns (CARs) of audit clients when information was revealed during and following congressional hearings. For audit firms marketing these tax shelters, two competing hypotheses could explain negative abnormal returns. First, the reputation of the audit firm may be impaired, reducing perceived quality of the audit (DeAngelo, 1981). Second, to the extent firm survival was threatened, the stock market may discount client stock prices because of concerns the CPA firm will no longer be available as a form of insurance (Menon and Williams, 1994). To our knowledge, this is the first study to examine a profession-wide spillover effect when members of the audit profession have been accused of wrongdoing.

To draw conclusions about audit competition, we measure CARs surrounding February 20, 2004, the KPMG Federal Grand Jury investigation announcement date, and May 25, 2004, the date EY announced it was the subject of a criminal inquiry. We examine six groups of audit clients: audit clients of each Big 4 firm, Midsize firms, and Small firms. Audit clients of all groups have significant negative CARs on the KPMG announcement date. We conclude that the market was concerned with potential diminishing competition among large audit providers. On the EY announcement date, CARs are significantly negative for clients of Midsize and Small firms. Audit clients of both KPMG and EY have significantly negative CARs on their respective investigation announcement dates; these negative returns may also be attributed to reputation loss and audit quality concerns. 
To address reputational spillover, we examine CARs surrounding November 18, 2003, the first day of Congressional hearings. Testimony on this date includes information about tax shelters sold by EY, KPMG, and PwC. Returns for all client groups are negative and significant. Our interpretation, in part, is that there is reputation damage to the profession as a whole because the negative market reactions are not limited to the clients of tax shelter providers singled out in the testimony. For audit clients of firms testifying at the hearings, there are other potential interpretations of the negative returns. The hearings allege compromised independence as a result of these tax shelters being sold to audit clients. To the extent the hearings were a precursor to criminal investigations, the market may have anticipated the future demise of one or more of these CPA firms.

We evaluate two other important dates, January 12, 2004 and August 29, 2005, for the market reaction of KPMG audit clients. On January 12, 2004, the KPMG announcement of tax practice personnel changes, we observe positive CARs. This reaction is consistent with a reputation explanation, as the firm appeared to be taking steps to address problems identified in the hearings. On August 29, 2005, when KPMG admitted to criminal wrongdoing and announced a deferred settlement agreement with the DOJ, we observe negative CARs. These results are consistent with KPMG's reputation being damaged by entering into such an agreement.

The remainder of this paper is structured as follows. Section 2 provides background information on the hearings and the history of tax shelters and tax shelter abuses. Section 3 reviews the literature and develops research questions and methodology. Section 4 describes the sample, descriptive statistics, and CAR estimation method. Section 5 summarizes results, Section 6 provides additional analyses, and Section 7 presents our conclusions. 


\section{Background}

\subsection{The Congressional Hearings}

Table 1 describes the event dates in the tax shelter timeline. On October 2, 2002, the U.S. Senate Permanent Subcommittee on Investigations of the Committee on Governmental Affairs began an investigation into development, marketing, and implementation of tax shelters by accountants, lawyers, financial advisors, and bankers. ${ }^{2}$ On November 18 and 20, 2003, the Subcommittee held hearings ${ }^{3}$ in which three of the Big 4 firms testified. ${ }^{4}$ The hearings underscored the extent of accounting firm involvement in marketing tax shelter products. Testimony and final report primarily focused on the activities of KPMG; ${ }^{5}$ however, EY and PwC also testified at the hearings.

\subsection{A history of tax shelters and tax shelter abuses}

Tax shelter registration requirements under Internal Revenue Code (IRC) Section 6111, define a "tax shelter" as any entity, plan, arrangement, or transaction, a significant purpose of which is the avoidance or evasion of Federal income tax, which a firm offers under conditions of confidentiality, and for which tax shelter promoters may receive fees in excess of $\$ 100,000$. IRC Section 6112 requires organizers and sellers of tax shelters to keep lists of investors and to make such lists available for inspection.

CPA firms began promoting tax shelters in the early 1990s, when contingent fee rules changed. The American Institute of Certified Public Accountants (AICPA) revised the Code of

\footnotetext{
${ }^{2}$ U.S. Senate, 2003, p. 1.

${ }^{3}$ The hearings were held on November 18 and 20,2003, with CPA firms testifying on the first day. The November 18 testimony can be viewed at: http://www.hsgac.senate.gov/subcommittees/investigations/hearings/u-s-tax-shelterindustry-the-role-of-accountants-lawyers-and-financial-professionals-day-1

The transcript can be found at (Item 4 on that page):

http://www.hsgac.senate.gov/search/?q=abusive\%20tax\%20shelters\&start=15\&as_sitesearch=\&page=2

${ }^{4}$ Also testifying at the Congressional hearings are various financial institutions, lawyers, investment advisors, and charitable organizations.

${ }^{5}$ Six partners from KPMG testified on November 18, while only one partner each from EY and PwC testified.
} 
Professional Conduct (Rule 302, Contingent Fees) on May 20, 1991, allowing accountants to engage in contingent fee billing for non-attest services. Substantial revenue potential appears to be the underlying reason accounting firms chose to provide tax shelter services to their clients.

\subsection{KPMG's involvement with tax shelters}

Testimony at the hearings indicated KPMG began aggressively creating and selling tax shelter products in 1997. According to a 2003 General Accounting Office (GAO) report, KPMG generated nearly $\$ 1.2$ billion (approximately $37 \%$ ) of its U.S. revenues from tax services during 2002. ${ }^{6}$ An interview with an unnamed former member of KPMG's Board of Directors states KPMG "...came to the party late. We drank more, and we stayed longer." ${ }^{7}$

The Subcommittee investigation also addressed concerns about KPMG's independence with respect to its audit clients. KPMG circumvented the contingent fee rules by developing "fixed fees" that were, in substance, contingent fees. ${ }^{8}$ Within KPMG, the head of the Department of Professional Practice - Tax (DPPT) took the position that fees based on projected client tax savings were contingent fees prohibited by AICPA Rule $302 .{ }^{9}$ The Congressional hearings noted a KPMG memorandum strongly objecting to the DPPT interpretation of Rule 302 because "many, if not most, of our Capital Transaction Services Group targets are officers/directors/shareholders of our assurance clients". ${ }^{10}$

\footnotetext{
${ }^{6} \mathrm{GAO}$ (2003a) Table 2, page 17.

${ }^{7}$ Quote taken from CorpWatch, Holding Corporations Accountable, "US: How an Accounting Firm went from Resistance to Resignation” by Lynnley Browning, The New York Times, August 2005. http://www.corpwatch.org/article.php?id=12575 (accessed September 29, 2006).

${ }^{8}$ In order to circumvent the "contingent fees" restriction, the fees charged by KPMG for BLIPS were called a "fixed fee", set at 7\% of the generated "tax loss" clients would achieve on paper. KPMG developed "basis points" (portions of the 7\% fee) which depended upon the size of the client's expected tax loss to determine their amount. The Subcommittee concluded in the case studies examined the fees charged by KPMG for their tax shelter products were clearly based upon the clients' projected tax savings (Part VI, Section B (5), page 113, paragraph 3 of the Permanent Subcommittee Report).

${ }^{9}$ Part VI, Section B(5), page 110, paragraph 3 of the Permanent Subcommittee Report, interview of Lawrence DeLap (10/30/03); memorandum dated 7/14/98, from Gregg Ritchie to multiple KPMG tax professionals, "Rule 302 and Contingency Fees - CONFIDENTIAL," Bates KPMG 0026557-58.

${ }^{10}$ Part VI, Section B (5), page 111, paragraph 1 of the Permanent Subcommittee Report.
} 
The Subcommittee described KPMG's steps to conceal its tax shelter activities, including its failure to abide by the disclosure requirements of IRC Sections 6111 and 6112. KPMG took the position that it did not develop, sell, or promote tax shelters, and, therefore, did not register and disclose any of its tax products. In addition, KPMG refused to comply with IRS document requests for lists of clients who purchased tax shelters.

During Subcommittee testimony, the head of KPMG's Tax Practice admitted "certain tax strategies previously offered by the firm, and the manner in which they were offered, were inconsistent with the role expected of a professional organization to which public trust and confidence are indispensable" (U.S. Senate, 2003). The Subcommittee concluded "although KPMG denies being a tax shelter promoter, the evidence established KPMG has devoted substantial resources to, and obtained significant fees from, developing, marketing, and implementing potentially abusive and illegal tax shelters ..., costing the U.S. Treasury billions of dollars in lost tax revenues" (U.S. Senate, 2003).

Although KPMG committed to structural, cultural, and institutional changes and agreed to dismantle its abusive tax shelter practice at the hearings, the firm did not issue any press release until January 12, 2004. The announcement indicated Jeffrey Stein, Deputy Chair of KPMG and former Vice Chair of Tax Services, would retire at the end of January 2004; Richard Smith, Jr. (then the head of Tax Service Practice) would be removed from office and assigned other duties; and Jeff Eischeid, the partner in charge of KPMG's Personal Financial Planning Practice, was placed on administrative leave (Accountingweb.com, 2004).

On February 20, 2004, The New York Times revealed that the U.S. Attorney for the Southern District of New York was conducting a federal grand jury investigation of KPMG for alleged participation in the sale of tax shelters (Johnson, 2004a). In May 2005, the U.S. Attorney 
notified KPMG of its imminent indictment. On June 5, 2005, Eugene O'Kelly, KPMG Chairman, stepped down due to a brain tumor. Timothy Flynn, a KPMG management committee member, was appointed Chairman. That same month, numerous articles expressed concern KPMG might not survive the tax shelter fallout. The Wall Street Journal noted on June 16, 2005 : "Federal prosecutors have built a criminal case against KPMG for obstruction of justice and the sale of abusive tax shelters, igniting a debate among top DOJ officials over whether to seek an indictment - at the risk of killing one of the four remaining big accounting firms" (Wilke, 2005). Days later, The Wall Street Journal reported the SEC was discussing a contingency plan if another large CPA firm failed (Solomon and Gullapalli, 2005).

Concerns over the possible demise of KPMG may have been mitigated by the Supreme Court's reversal of the Arthur Andersen conviction on May 31, 2005. Editorials in The Wall Street Journal and The Washington Post in mid-June 2005 made it clear a death sentence for KPMG was not viewed as prudent, given the court's decision (Anonymous, 2005a, 2005b). These editorials noted a need for more, not fewer, CPA firms and found no justice in putting the employees of KPMG out of work.

On June 13, 2005, Timothy Flynn met with DOJ officials and admitted to "selling shelters to help people avoid taxes" (Reilly, 2007). On June 16, 2005, KPMG issued a press release 'taking full responsibility for 'unlawful conduct by former KPMG partners' in offering tax services" (KPMG LLP, 2005). The release stated the firm had "instituted firm-wide structural, cultural, and governance reforms to ensure the highest ethical standards," including "significant change in its business practices," would "remain in discussions with the Department of Justice (DOJ) and continue to cooperate fully in its investigation," and looked "forward to a resolution that recognizes the significant reforms the firm has already made in response to this 
matter, while appropriately sanctioning the firm for this wrongdoing" (KPMG LLP, 2005). Shortly thereafter, the DOJ announced it was considering a settlement.

On August 29, 2005, KPMG issued a press release announcing a settlement with the DOJ and the IRS. As part of the agreement, KPMG agreed to three payments to the U.S. government totaling \$456 million to avoid further legal action. Under the deferred prosecution agreement, charges against KPMG would be dismissed on December 31, 2006, if the firm complied with the terms of the agreement. The DOJ announcement stated: "KPMG LLP has admitted to criminal wrongdoing... and ... admitted that it engaged in a fraud that generated at least $\$ 11$ billion dollars in phony tax losses" (United States Department of Justice, 2005). On February 15, 2007, The Wall Street Journal reported "KPMG now is emerging from what some at the firm call a near-death experience" (Reilly, 2007). The deferred criminal charges were ultimately dismissed because of satisfactory reforms made by the firm in its tax practice as required under the settlement agreement.

\subsection{EY's involvement in tax shelters}

On July 2, 2003, EY issued a press release concurrently admitting to the sale of shelters to clients between 1998 and 2002 and announced a settlement with the DOJ and the IRS. Under this settlement, EY paid a $\$ 15$ million civil penalty, turned over a list of clients who purchased the tax shelters, and pledged to institute systematic reforms within its tax practice (Cassell and McKinnon, 2003). IRS Commissioner Mark Everson stated, "This represents a real breakthrough and is a good working model for agreements with practitioners. ... [W]e are trying to differentiate between those who cooperate with the IRS, who try to remedy past mistakes and who seek transparency in their dealings with the Service, and those others who simply refuse and 
continue to peddle abusive transactions. Our intention is to differ in our approach to them based on their behavior."

Despite the July 2003 settlement, on May 25, 2004, EY announced it was under criminal investigation regarding the tax shelter implicated in its $\$ 15$ million civil fine (Johnson, 2004b). On May 31, 2007, the financial press reported EY would likely not face indictment (Reilly and Davies, 2007; Davies and Bray, 2007). On March 1, 2013, EY announced a settlement with the U.S. Attorney's office and \$123 million in fines and penalties, admitting it used fraudulent tax shelters to help its clients avoid or defer taxes during the 1998 to 2006 period. $^{11}$

\subsection{PwC's involvement in tax shelters}

On June 26, 2002, PwC announced a settlement with the DOJ and the IRS related to shelter products. ${ }^{12} \mathrm{PwC}$ agreed to pay a $\$ 10$ million penalty, turn over a list of tax shelter clients to the IRS, and make comprehensive changes to the firm's internal quality control procedures. PwC testified at the Congressional hearings that they had disbanded the group selling abusive shelters late in 1999 (United States Senate 2003, pp 99-100).

\subsection{Other CPA firms and tax shelters}

Other CPA firms were not mentioned in the Congressional hearings. However, BDO Seidman, LLP (Seidman) involvement in tax shelter-related activities was in the news during the 2002-2004 time period. Seidman is part of our Midsize firm group. The impact of Seidman's involvement in tax shelters on the Midsize group is discussed in Section 6 of this paper.

Insert Table 1 here

\footnotetext{
${ }^{11}$ Available at: http://online.wsj.com/article/SB10001424127887324662404578334591048912854.html

${ }^{12}$ Price Waterhouse and I.R.S. Settle Tax Shelter Dispute. The New York Times. June 28, 2002, Late Edition, Final Section C, Column 4, page 2. http://www.nytimes.com/2002/06/28/business/pricewaterhouse-and-irs-settle-taxshelter-dispute.html In this article, the IRS described the penalty paid by $\mathrm{PwC}$ as 'substantial', whereas the PwC spokesman, David Nestor, described the penalty as 'insignificant' - the amount of the penalty paid by PwC was not disclosed in this newspaper article.
} 


\section{Literature review, research questions and research method}

\subsection{Literature review}

Our study is based on two streams of research: auditor quality and auditors as a form of insurance. The need to mitigate information asymmetry between managers and stockholders motivates the demand for a high quality audit. DeAngelo (1981) notes it is costly and almost impossible for stockholders to observe audit quality directly; therefore, stockholders rely on audit quality surrogates. DeAngelo (1981) also asserts larger audit firms have stronger incentives to provide high quality audits due to the amount of quasi-rents they are likely to lose if their reputation is diminished. Prior literature documents a negative impact on client firms' stock prices when auditor reputation is tarnished.

Auditor reputation is a common surrogate for audit quality in academic research (Watkins et al., 2004). Audit quality has been examined empirically in terms of the market impact on audit clients (Baber et al., 1995; Chaney and Philipich, 2002; Krishnamurthy et al., 2006; Weber et al., 2008; Dee et al., 2011), as well as audit clients' stock price reaction to deterioration of their auditor's reputation (Menon and Williams, 1994; Chaney and Philipich, 2002; Hillison and Pacini, 2004; Barton, 2005; Krishnamurthy et al., 2006; Weber et al., 2008). Specifically, Chaney and Philipich (2002) find Arthur Andersen's clients experienced negative abnormal returns persisting for up to two days following the announcement of document shredding, concluding "....investors downgraded the quality of the audits performed by Andersen" (Chaney and Philipich, p.1244). Furthermore, Lennox (1999) documents a favorable stock market reaction when companies switch to a large auditor.

The insurance hypothesis is based on the premise that auditors are valued by the market both as assurance service providers and as providers of insurance to indemnify investors against 
losses in the event of an alleged audit failure. This hypothesis has been empirically tested using cases of audit firm bankruptcy (Menon and Williams, 1994; Baber et al., 1995), as well as surrounding rumors of potential audit firm bankruptcy (Pacini and Hillison, 2003; Hillison and Pacini, 2004).

Both reputation and insurance explanations can account for negative price reaction to audit clients when their auditor is perceived as providing a substandard audit (Baber et al., 1995; Hillison and Pacini, 2004; Dee et al., 2011). Dee et al. (2011) find a negative market reaction to DT clients following the news of Public Company Accounting Oversight Board (PCAOB) sanctions. This reaction is significantly more negative for financially-distressed firms. In an attempt to distinguish between the two explanations, Willenborg (1999) finds evidence suggesting the insurance-based demand for IPO audits helps explain the relationship between auditor choice and underpricing ${ }^{13}$. Finally, Lennox (1999) finds large audit firms do not suffer a reduction in demand for their services when facing reputation-damaging criticisms, noting the insurance hypothesis can explain the lack of evidence for reputation effects.

Negative market reaction to clients of scrutinized auditors is not limited to U.S. firms. Skinner and Srinivasan (2012), in connection with PwC's Japanese affiliate's (ChuoAoyama) failed audit of a large Japanese cosmetics company, analyze the importance of auditors' reputation for quality in a country where litigation does not play a critical role. They find a large number of ChuoAoyama's clients defected, consistent with the auditor reputation hypothesis. They also find a significant negative stock price reaction on the date $\mathrm{PwC}$ announced they were sending auditors from the U.S. and the U.K. to address ChuoAoyama's problems. Weber et al. (2008) study the market impact on KPMG's German clients surrounding the highly-publicized

\footnotetext{
${ }^{13}$ Willenborg (1999) partitioned his sample of firms into start-up companies (IPOs) and established companies, based on the notion for development stage firms, the quality of the audit should not matter and, therefore, the insurance demand for auditing is likely to dominate the information-based demand.
} 
accounting scandal at ComROAD AG, and find negative abnormal returns of 3\%. Weber et al. (2008) find an increase in the number of audit clients dropping KPMG as their auditors in the year of the ComROAD scandal, providing further support for auditor reputation as a surrogate for audit quality. Weber et al. (2008) also find, in the German legal environment which limits damages from suing the auditor, a negative stock price reaction for KPMG clients surrounding the public disclosure of the ComROAD AG accounting scandal. They conclude this negative reaction is due to tarnished auditor reputation rather than the insurance hypothesis. ${ }^{14}$

\subsection{Research question 1: Audit market concentration}

Our first research question examines market concern about audit market concentration, as some of the large firms faced criminal investigations of tax shelter activities. Competing views remain as to whether allowing the collapse of another large firm is good for the market. First, with the shrinking number of large audit firms, companies may have difficulty finding a high quality auditor. ${ }^{15}$ Conversely, without the threat of failure, firms may not provide appropriate audit quality. William McDonough, former head of PCAOB, testified before the House Financial Services Committee, stating the "lack of apparent competition" in accounting is a difficult public policy issue. He viewed it as a mistake to let a firm think it is too big to fail. ${ }^{16}$

We examine audit concentration by investigating CARs for six groups (each of the Big 4 firms, Midsize firms, and the Small firms) of audit clients on the dates when criminal

\footnotetext{
${ }^{14}$ At the time of the ComROAD AG scandal, there was a limit of 4 million Euros for which an auditor could be held liable under Germany and European Community laws.

${ }^{15}$ The GAO (2003b) survey of CFO's of Fortune 1000 firms regarding auditor choice following the Andersen collapse finds $88 \%$ of the CFO's stated they would not consider a non-Big 4 auditor to replace their current Big 4 auditor. These CFO's also raised concerns the further consolidation of CPA firms would result in too few auditor choices; $82 \%$ of the CFO's believed four large auditors was at or below the minimum number required.

Furthermore, because of the need to have an auditor capable of auditing a client with global operations, as a practical matter, their choice was often actually limited to only one or two auditors.

${ }^{16}$ House Committee on Financial Services, Subcommittee on Capital Markets, Insurance, and Government Sponsored Enterprises, Hearing on Oversight of the Public Company Accounting Board, Thursday, June $24,2004$. Accessed at: http://archives.financialservices.house.gov/archive/hearings318.shtml
} 
investigations were announced for KPMG and EY. If the market was concerned about audit market concentration and these investigations were perceived as bad news, we would expect to see negative CARs on the announcement date for clients of all auditors.

We also expect CARs of clients of CPA firms under investigation to be negative. There are three potentially competing explanations for these negative CARs. First, investors in clients of investigated firms may be concerned about high audit market concentration. Second, the firm's reputation could be negatively impacted by the criminal investigation. Finally, if the criminal investigation signals the potential demise of a CPA firm, market reaction could be attributed to the insurance hypothesis.

\subsection{Research question 2: Reputational spillover}

Our second research question examines whether sale of tax shelters had a reputational spillover effect. We address this question from two perspectives. First, we evaluate whether the reputation of the profession may have been damaged from tax shelter events by examining CARs of audit clients of the Big 4, Midsize, and Small CPA firms on the first day of the Congressional hearings. Although the hearings brought out facts about specific firms and individuals, there could be spillover to the reputation of CPAs in general. If reputational damage was professionwide, we would expect negative CARs for all clients. ${ }^{17}$

Second, we examine whether the reputation of the investigated CPA firms may have been damaged, by assessing CARs for audit clients of KPMG and EY when criminal investigations were announced and, for KPMG, when the charges were resolved (the EY criminal investigation was not resolved until March 2013). There are differing interpretations of negative CARs for the

\footnotetext{
${ }^{17}$ We attempt to measure whether the magnitude of the CARs for the firms was related to shelters sold to audit clients. The GAO (2005) report indicates a number of clients purchased shelter products from their auditor, but a list of which clients did this was unavailable. We tried to obtain lists of companies and individuals who subsequently sued the CPA firms to recover losses related to the shelters but were unable to do so.
} 
named firms. Quality control or independence concerns may have damaged the firm's reputation. In addition, any indication the firm may face criminal investigation could have implications under the insurance hypothesis.

The question of reputational spillover, especially when a CPA firm's non-audit practice potentially affects the firm's audit practice or the reputation of all CPAs, is important. Understanding this spillover effect provides insight into firm and profession policies and practices, including disciplinary actions of professionals, inspections, and quality control issues. If the actions of a few individuals hurt the entire profession, then more severe disciplinary actions may be needed. Further, if non-audit services damage the reputation of a firm or the profession, this may impact a firm's internal quality controls and PCAOB inspection standards. In a study of whether the results of peer reviews signal audit quality, Casterella et al. (2009) find the factor score incorporating tax shelter activities is positive and significantly associated with the total number of weaknesses identified in auditors' self-disclosed peer-review reports, suggesting lower quality audits.

\section{Identification of observations, descriptive statistics, and CARs estimation method}

\subsection{Data collection and descriptive statistics}

For each event date, we obtain all auditor-client information from Audit Analytics. We

eliminate firms without the necessary data on both CRSP and Compustat and those announcing an auditor switch between the effective date of the Audit Analytics information and the event date. See Table 2, Panel A. We divide the remaining observations into six groups: clients of each of the Big 4, Midsize firm clients, and all others (Small). Midsize firms, based on the Audit Analytics auditor size rankings classifications, include Grant Thornton, LLP; BDO Seidman, LLP; Crowe Chizak, LLP; McGladrey and Pullen, LLP; and Plante and Moran, LLP. Table 2, 
Panel B shows descriptive statistics for the November 18, 2003 observations. Panel B shows the clear domination of Big 4 firms, in terms of number of clients and client size, with Big 4 clients comprising about $83 \%$ of the observations, Midsize clients $7 \%$, and Small clients $10 \%$.

Insert Table 2 here

\subsection{Calculation of mean cumulative abnormal returns}

We obtain mean cumulative abnormal returns (CARs) using Eventus and a window of ($1,+1)$ around each event date. ${ }^{18}$ CARs are calculated using the size index, own market ${ }^{19}$ option in Eventus, which matches each stock to a market and size decile using the CRSP reported exchange and decile number as of the event date. Non-trading dates are converted to the next trading date. The estimation period is 255 days, ending 46 days before the event date, to minimize contamination of the event window. The minimum required number of returns for the calculation of CARs is three.

\section{Results}

\subsection{Audit market concentration}

Results for the February 20, 2004, KPMG's Grand Jury investigation announcement are shown in Table 3, Panel A. Mean and median CARs for all Big 4 firms and the Midsize group are negative and significant at the 0.001 level. The Small group's mean and median CARs are significant at the 0.001 and 0.05 levels, respectively. These results strongly suggest the market was concerned about potential loss of a large audit firm. Mean CARs for the Big 4 firms range

\footnotetext{
${ }^{18}$ MacKinlay (1997) notes it is difficult to make generalizable conclusions when detecting a non-zero abnormal return due to adequacy concerns of the event study methodology. To address this limitation, MacKinlay (1997) suggests, among other means, shortening the event window, as we have done in our study. In addition to the (-1, $+1)$ CAR window reported in our analyses, we also obtain CARs for alternative windows $[(-2,+2)$ and $(-3,+3)]$ around each event date, and do not find significant differences in the results shown in Tables 3,4 , and 5 .

${ }^{19}$ The size index, own market option helps ensure 'abnormal' returns are based upon firms with similar characteristics while controlling simultaneously for economic effects shared by these firms.
} 
from $-0.71 \%$ for DT clients to $-1.60 \%$ for EY clients. ${ }^{20}$ Mean CARs for the Midsize and Small providers are lower at $-1.82 \%$ and $-1.73 \%$, respectively. The low CARs for these groups suggest that if another large CPA firm failed, audit quality, for smaller firm clients, in particular, could be compromised. This explanation is plausible, given large CPA firms were giving up both small and high-risk audit clients during this period (2003-2004), as the time demands of SOX Section 404 implementation strained the large CPA firms' resources (Landsman et al. 2009). The loss of another large audit provider could further strain the ability of Small firm clients to find high quality auditors.

Significant negative CARs for KPMG clients $(-1.07 \%)$ have an alternative explanation under the insurance hypothesis. Since the hearings focused on KPMG, negative returns for KPMG clients may reflect concerns KPMG might not survive to indemnify investors for losses awarded from settlements and lawsuits.

CARs on May 25, 2004, the EY criminal inquiry announcement date, are shown in Table 3, Panel B. For the Big 4 firms, mean CARs are negative (-0.06\%) and significant (p-value $=.001)$ only for EY. These findings are consistent with both the reputation and the insurance hypotheses. The EY announcement is not potentially as serious as the KPMG announcement, since EY was only facing an inquiry and not a grand jury investigation. Further, the market may not have viewed the EY inquiry as serious, since EY had previously announced a settlement with the IRS and paid a fine in the summer of 2003. Although EY testified in the Congressional hearing, its visibility was significantly less prominent than KPMG. Thus, the market may not have viewed

\footnotetext{
${ }^{20}$ It is noteworthy the negative CARs for EY (-1.60\%) are larger than the KPMG (-1.07\%) on this date. According to Cahan and Zhang (2006), out of the 368 firms switching from Andersen to the other Big 4 firms for their 2002 audits, 113 (or 30\%) switched to EY; 27\% switched to KPMG; 26\% switched to DT; and the remainder (17\%) switched to PwC. We speculate since a larger portion of Andersen's audit clients switched to EY after the bankruptcy of Andersen perhaps these investors were more sensitive to the potential impact of the tax shelter issue on EY than KPMG on that particular date.
} 
EY as being significantly at risk on the May 25,2004 date. ${ }^{21}$ We do not find large negative CARs for other audit providers on this date. We speculate the market had already adjusted when the KPMG Federal Grand Jury announcement was made on February 20, 2004; also, KPMG was ordered to release tax shelter data under the IRS probe announced on May 4, 2004, a few weeks before the EY criminal investigation announcement.

For Midsize and Small firms, we find significant negative mean CARs, $-0.54 \%$ (pvalue $=0.05$ ) and $-0.38 \%$ ( $\mathrm{p}$-value $=0.05$ ), respectively. This suggests residual concern about the continued existence of EY, as the failure of EY could cause realignments which might be most costly for the smallest audit firms. The significant mean and median tests for DT and PwC consistently suggest a positive market reaction to the stock price of these audit clients, potentially signaling the market looked favorably on the quality of the audits performed by DT and $\mathrm{PwC}$ on that date.

\section{Insert Table 3 here}

\subsection{Reputational spillover}

Our second research question examines whether the sale of shelters had a reputational spillover effect on the audit practice and caused a corresponding negative market reaction to audit clients of the named firms. We examine the mean CARs of the six groups on the first day of the Congressional hearing, November 18, 2003. Results are shown in Table 4.

Although the hearing only included information about shelters sold by EY, KPMG, and $\mathrm{PwC}$, the mean abnormal returns for all groups are negative: significant at 0.10 for clients of EY and KPMG, 0.05 for DT, Midsize, and Small CPA clients, and 0.001 for PwC clients. Negative

\footnotetext{
${ }^{21}$ We note the article published in the Late Edition of the Wall Street Journal on May 24, 2004 ('Ernst \& Young Faces Tax-Shelter Inquiry' by Jonathan Weil) and subsequent press articles published by various news organizations on May 25, 2004 do not mention either DT or PwC - this possibly explains the positive and significant CARs shown in Table 3, Panel B for the audit clients of DT and PwC around the May 25, 2004 date.
} 
mean (median) CARs for Big 4 clients range from $-0.40 \%$ to $-0.54 \%(-0.29$ to $-0.45 \%)$, and are approximately $-1.00 \%(-0.45 \%$ to $-0.60 \%)$ for the clients of Midsize and Small firms. The significant negative CARs for DT, Midsize, and Small firms suggest a reputation spillover to the profession on the first day of the hearings.

For clients of firms testifying in the hearings, there are other potential interpretations of negative returns. The firms' reputations were almost certainly damaged, as the hearings included allegations of compromised independence and aggressive marketing of shelters. To the extent the hearings were a precursor to criminal investigations, the market may have anticipated the demise of one or more CPA firms. This latter explanation, although plausible, is unlikely for $\mathrm{PwC}$ and EY, since both previously announced settlements with the IRS.

Insert Table 4 here

We evaluate additional event dates for KPMG after the hearings, the results of which are shown in Table 5. On January 12, 2004, the date KPMG announced tax department personnel changes, we observe significant positive mean and median CARs ( $p$-value $=0.05$ ). This result indicates the announcement was likely viewed as a positive step towards rectifying problems in KPMG's tax practice and rehabilitating the firm's reputation. We find no market reaction on June 16, 2005, the date KPMG revealed it was in discussions with the DOJ, likely because the announcement did not contain either a positive or a negative indication of the status of those discussions. On August 29, 2005, KPMG admitted to criminal wrongdoing and announced a deferred settlement agreement with the DOJ. KPMG clients experienced $-0.16 \%(-0.27 \%)$ mean (median) abnormal returns (significant at $0.01(0.10))$. The negative reaction suggests continued damage to the firm's reputation.

Insert Table 5 Here 


\section{Additional Analyses}

\subsection{Alternative event dates}

We also examine CARs on May 31, 2005, the day the Supreme Court reversed the Arthur Andersen conviction. Results on this date, untabulated, are not significant.

\subsection{Schipper and Thompson (1983) regression model testing for event date clustering}

Given the common event-date, we also test for significance using the Schipper and Thompson (1983) regression model controls for cross-sectional dependence in residuals. Results for February 20, 2004 (Table 6, Panel A) show our variable of interest, Event, is negative and significant for all audit groups except DT. These findings are consistent with our significant negative mean and median CARs findings in Table 3, Panel A, and thus are robust to crosscorrelation dependence of residuals. Given that Event of DT clients is not significant, we need to be cautious in interpreting the CARs result for DT clients in Table 3, Panel A.

For the EY criminal investigation date (Table 6, Panel B), Event is not significant for any audit-group. The findings in Table 6, Panel B suggest our Table 3, Panel B findings are not robust to residual dependence. Finally, in Table 6, Panel C, we find Event is negative and significant for both the Midsize and Small auditor-groups, consistent with Table 4. The lack of significant results for all other audit groups suggests our prior finding in Table 4 of significant negative mean CARs for DT, EY, KPMG, and PwC are not robust to cross-correlation among residuals. $^{22}$

\section{Insert Table 6 here}

\footnotetext{
${ }^{22}$ An alternative explanation of our Tables 3-5 findings is the potential presence of confounding events or disclosures at the Company level during our event dates, such as earnings announcements; mergers; acquisitions; stock purchases; equity issuances; and bankruptcy filings. Consistent with prior research (Thompson et al., 1987; Baber et al., 1995; Dee et al., 2011), we repeat our analyses in Tables 3-5, and find no evidence these potentially confounding events or disclosures influenced our mean CARs reported in any of our windows in Tables 3-5.
} 


\subsection{Multivariate analysis}

To further assess negative market reaction surrounding the Congressional hearings, we conduct a multivariate analysis by regressing CARs surrounding the first day of the hearings on proxies for auditor reputation and auditor insurance value. ${ }^{23}$ The dependent variable is the threeday CARs of Big 4 audit clients testifying during the hearings; KPMG, EY and PwC. Our model is as follows: ${ }^{24}$

$$
\begin{gathered}
\text { CARs }_{\mathrm{i}, \mathrm{t}}=\alpha_{0}+\alpha_{1}\left(\text { Pr_Bankrupt }_{\mathrm{i}, \mathrm{t}}\right)+\alpha_{2}\left(\text { LnAsset }_{\mathrm{i}, \mathrm{t}}\right)+\alpha_{3}\left(\mathrm{BM}_{\mathrm{i}, \mathrm{t}}\right)+\alpha_{4}\left(\text { Leverage }_{\mathrm{i}, \mathrm{t}}\right)+ \\
\alpha_{5}\left(\text { SaleGrowth }_{\mathrm{i}, \mathrm{t}}\right)+\alpha_{6}\left(\text { ROA }_{\mathrm{i}, \mathrm{t}}\right)+\alpha_{7}\left(\text { InstHold }_{\mathrm{i}, \mathrm{t}-1}\right)+\alpha_{8}\left(\text { Switcher }_{\mathrm{i}, \mathrm{t}}\right)+ \\
\alpha_{9}\left(\text { AASwitcher }_{\mathrm{i}}\right)+\alpha_{10}\left(\text { FeeRatio }_{\mathrm{i}, \mathrm{t}}\right)+\mathrm{e}_{\mathrm{i}, \mathrm{t}}
\end{gathered}
$$

, where ${ }^{25}$

CARs = the firm specific cumulative abnormal returns in a three-day event window (-1, $+1)$, where day 0 is the first hearing date $(11 / 18 / 2003)$;

Pr_Bankrupt $=$ the Zmijewski (1984) financial distress measure ${ }^{26}$ for firm $\mathrm{i}$ at fiscal year-end $\mathrm{t}$;

LnAsset $\quad=$ the natural $\log$ of total assets $(A T)$, in million dollars for firm $\mathrm{i}$ at fiscal year-end $\mathrm{t}$;

$\mathrm{BM}=$ the book value of equity $(C E Q)$ divided by the market value of equity $\left(C S H O * P R C C \_F\right)$ for firm i at fiscal year-end $\mathrm{t}$;

Leverage $\quad=$ the ratio of total debt $(L T)$ to total assets $(A T)$ for firm $\mathrm{i}$ at fiscal year-end $\mathrm{t}$;

SaleGrowth $\quad=$ the growth rate in sales calculated as the change in sales (SALE) from time $\mathrm{t}-1$ to time $\mathrm{t}$, scaled by $(S A L E)_{\mathrm{t}-1}$ of firm $\mathrm{i}$ at fiscal year-end $\mathrm{t}$;

$\mathrm{ROA}=$ the return on assets calculated as earnings before interest and tax $(E B I T)$ divided by total assets $(A T)$ for firm $\mathrm{i}$ at fiscal year-end $\mathrm{t}$;

InstHold $\quad=$ the percentage of shares owned by institutional shareholders at the beginning of the fiscal year $\mathrm{t}$;

Switcher $\quad=1$ if firm i switches auditors in year $\mathrm{t}$ or $\mathrm{t}-1$, and 0 otherwise, using (DISMISS_KEY);

AASwitcher $=1$ if firm i switched from Arthur Andersen in years 2000-2003, and 0 otherwise, using (DISMISS_KEY); and

FeeRatio $\quad=$ A proxy for auditor independence. We use the fee ratio measures as the ratio of non-audit fees (NON_AUDIT_FEES) to total fees

(TOTAL_FEES) for firm $i$ at fiscal year-end $t^{27}$

\footnotetext{
${ }^{23}$ See Baber et al. (1995), Krishnamurthy et al. (2006), and Dee et al. (2011).

${ }^{24}$ We excluded the going concern opinion variable included in prior research because there were no firms in our sample receiving this type of audit opinion in the year prior to 2003 (2002 fiscal year).

${ }^{25}$ Each variable is obtained from Compustat except for bold variables (definitions), which are from Audit Analytics.

${ }^{26}$ The Zmijewski (1984) measure (Zscore) $=-4.336-4.513 *$ ROA + 5.679*FINL + 0.004*LIQ, where:

$\mathrm{ROA}=$ Earnings before interest and taxes $(E B I T)$, scaled by total assets $(A T)$;

FINL = Financial leverage equals total liabilities $(L T)$ divided by total assets $(A T)$; and

LIQ = Liquidity is calculated as total current assets $(A C T)$ divided by total current liabilities $(L C T)$.
} 
Table 7 includes descriptive statistics and regression results. The analysis is conducted for all clients combined and separately by firm. The KPMG and PwC analysis provides no evidence of either the insurance or reputation hypotheses. For EY, we find BM and ROA are significantly positive ( $\mathrm{p}$-value $<0.01$ and $\mathrm{p}$-value $<0.05$, respectively). Prior research finds firms with low book-to-market ratios and low ROAs have greater incentives to manipulate accounting performance (Baber et al., 1995; Krishnamurthy et al., 2006; Dee et al., 2011). Our findings that EY clients with greater book-to-market ratio and greater ROA are associated with significantly higher CARs in the hearing event window support the reputation hypothesis. Alternatively, prior research finds low book-to-market firms and low ROA firms, and their auditors, are more likely to be sued (Shu 2000; Dee et al., 2011). Under the insurance hypothesis, positive BM and ROA could indicate these firms and their auditors are less likely to be sued, resulting in significantly higher CARs. Furthermore, our combined results appear to be driven by EY audit clients.

\section{Insert Table 7 here}

We also conduct the equation (1) regression solely for KPMG clients surrounding the Grand Jury investigation announcement on February 20, 2004; results are shown in Table 8. We find a significant negative association between CARs and audit client size ( $\mathrm{p}$-value $<0.05)$. This finding suggests market reaction to KPMG clients is most likely due to the insurance hypotheses, since auditor lawsuits are more likely for auditors of larger firms. Consistent with findings in Table 7, the significant positive association between CARs and BM (p-value < 0.01) suggests the negative CARs are due to both the reputation and insurance explanations. Furthermore, we find a significant positive association between leverage and CARs ( $\mathrm{p}$-value $<0.05$ ). This finding is 
counter to expectations. A negative coefficient on leverage is expected; therefore, the findings in Tables 7 and 8 are not conclusive for any one explanation over another. ${ }^{28}$

Insert Table 8 here

\subsection{Seidman impact on Midsize firms analyses}

Given Seidman was in the public press for tax shelter activities during our analysis period, we repeat our analyses for the Midsize group (Tables 3 and 4), excluding Seidman clients to assess reputational spillover. Our findings and conclusions (in untabulated results) are similar, providing further evidence of a reputational spillover effect.

\section{Conclusions}

This paper provides a unique summary of the U.S. tax shelter controversy, starting with Congressional hearings in 2003 and ending with KPMG's announcement of a deferred settlement arrangement with the DOJ in 2007. Using tax shelter related events, we examine stock market concerns about auditor concentration, and effects on both the reputation of the accounting profession and the individual Big $4 \mathrm{CPA}$ firms subject to investigation. We find large negative returns of audit clients of all providers when the KPMG grand jury investigation was announced. Because the returns of all audit clients were negative, we conclude the market was concerned competition among large audit providers would be diminished, making it difficult to find independent, high quality audit and non-audit providers.

The announcement of the EY criminal inquiry indicates negative returns for clients of EY, Midsize, and Small audit providers. Negative returns for EY clients are consistent with a negative reputation effect. The negative return of Small providers is consistent with market

\footnotetext{
${ }^{28}$ For both Tables 7 and 8, we use alternative auditor independence measures for FeeRatio, suggested by Krishnamurthy et al. (2006), including $\log$ (audit fees) and $\log (1+$ audit fees), and (in untabulated results) our findings are consistent with those reported in Tables 7 and 8.
} 
concerns about audit concentration, since any threat to the large audit providers would potentially have the greatest impact on smaller companies.

The market reaction of all clients is negative on the first day of Congressional hearings. Because only three Big 4 CPA firms testified, we conclude the hearings had a negative reputational impact on the entire profession, including firms not directly implicated in tax shelter activity. We test returns on two additional dates: the day KPMG announced reforms in its tax practices and the day KPMG publicly admitted criminal wrongdoing and settled with the DOJ. Client returns on both days are negative and consistent with the reputation hypothesis.

Our findings are subject to certain limitations. There could be other important omitted variables which explain the stock price variations and their relationships to auditor reputation and the spillover effect around our event dates. Also, our study focuses on dates surrounding the release or broadcast of what we believe are the key tax shelter event dates between 2003 and 2005. It is possible there are other important dates during this period (e.g., dates where Internetrelated rumors were spread, especially related to KPMG's status). We focus on the dates we believe are key dates to test our research questions. 


\section{References}

Accountingweb.com., 2004. KPMG Makes Management Changes After Recent Tax Shelter Probe. Available at: http://www.accountingweb.com/topic/firm-news/kpmg-makes-managementchanges-after-recent-tax-shelter-probe

Anonymous., 2005a. Gunning for KPMG. The Wall Street Journal (Eastern edition). New York, N.Y.: June 20, 2005, pg. A1.

Anonymous., 2005b. Don't destroy KPMG. The Washington Post, June 21, 2005, Tuesday, Final Edition, Editorial, pg. A20.

Baber, W.R., Kumar, K.R., Verghese, T., 1995. Client security price reactions to the Laventhol and Horwath bankruptcy. Journal of Accounting Research, 33(2), 385-395.

Barton, J., 2005. Who cares about auditor reputation? Contemporary Accounting Research, 22(3), 549-586.

Cahan, S.F., Zhang, W., 2006. After Enron: Auditor conservatism and ex-Andersen clients. The Accounting Review 81(1), pp. 49-82.

Cassell, B., McKinnon, J.D., 2003. Ernst to pay $\$ 15$ million in IRS case. The Wall Street Journal (Eastern Edition). N.Y.: July 3, 2003: pg. A3.

Casterella, J.R., Jensen, K.L., Knechel, W.R., 2009. Is self-regulated peer review effective at signaling audit quality? The Accounting Review, 84(3), 713-735.

Chaney, P. K., Philipich, K.L., 2002. Shredded reputation: The cost of audit failure. Journal of Accounting Research, 40(4), 1221-1245.

Cowan, A.R., 1992. Nonparametric event study tests. Review of Quantitative Finance and Accounting, 2(4), 343-358.

Davies, P., Bray, C., 2007. Ernst tax case may expand. The Wall Street Journal (Eastern edition). New York, N.Y.: September 13, 2007, pg. C.6

DeAngelo, L.E., 1981. Auditor size and audit quality. Journal of Accounting and Economics, 3(3), 183-199.

Dee, C.C., Lulseged, A., Zhang, T., 2011. Client stock price reaction to PCAOB sanctions against a Big 4 auditor. Contemporary Accounting Research, 28(1), 263-291.

General Accounting Office (the GAO has since changed its name), 2003a. GAO-03-864, United States General Accounting Office, Report to the Senate Committee on Banking, Housing, and Urban Affairs and the House Committee on Financial Services, "Public Accounting Firms Mandated Study on Consolidation and Competition." 
General Accounting Office (the GAO has since changed its name), 2003b. GAO-03-1158, United States General Accounting Office, Report to the Senate Committee on Banking, Housing, and Urban Affairs and the House Committee on Financial Services, "Accounting Firm Consolidation: Selected Large Public Company views on Audit Fees, Quality, Independence, and Choice."

Government Accountability Office, 2005. United States Government Accountability Office, Report to the Ranking Minority Member, Permanent Subcommittee on Investigations, Committee on Homeland Security and Governmental Affairs, U.S. Senate: "Tax Shelters: Services Provided by External Auditors."

Hillison, W.A., Pacini, C., 2004. Auditor reputation and the insurance hypothesis: The information content of disclosures of financial distress of a major accounting firm. Journal of Managerial Issues, 16(1), 65-86.

Johnson, D. C., 2004a. Grand jury is investigating KPMG's sale of tax shelters. The New York Times, February 20, 2004.

Johnson, D. C., 2004b. Ernst \& Young says it faces criminal inquiry on shelters. The New York Times, May 25, 2004. Section C; Column 5; Business/Financial Desk; Pg. 2.

KPMG LLP, 2005. Statement Regarding Justice of Department Matter dated June 16, 2005. Available at: http://www.justice.gov/usao/nys/pressreleases/August05/kpmgdpagmt.pdf

Krishnamurthy, S., Zhou, J., Zhou, N., 2006. Auditor reputation, auditor independence, and the stock-market impact of Andersen's indictment on its client firms. Contemporary Accounting Research, 23(2), 465-490.

Landsman, W.R., Nelson, K.K., Rountree, B.R., 2009. Auditor switches in the pre- and postEnron eras: Risk or realignment? The Accounting Review, (84)2, 531-558.

Lennox, C.S., 1999. Audit quality and auditor size: An evaluation of reputation and the deep pockets hypothesis. Journal of Business Finance and Accounting 26, 779-805.

MacKinlay, A. C., 1997. Event studies in economics and finance. Journal of Economic Literature, 35(1), 13-39.

Menon, K., Williams, D.D., 1994. The insurance hypothesis and market prices. The Accounting Review, 69(2), 327-342.

Pacini, C., Hillison, W.A., 2003. Client firm market reaction to regulatory action against a major accounting firm. Journal of Economics and Finance, 27(3), 279-299. 
Patell, J.M., 1976. Corporate forecasts of earnings per share and stock price behavior: Empirical tests. Journal of Accounting Research, 14(2), 246-274.

Reilly, D., 2007. How a chastened KPMG got by tax-shelter crisis. The Wall Street Journal, February 15, 2007.

Reilly, D., Davies, P., 2007. Tax-shelter indictments leave a cloud over Ernst. The Wall Street Journal (Eastern edition). New York, N.Y.: May 31, 2007. pg. C.1.

Schipper, K., Thompson, R., 1983. The impact of merger-related regulations on the shareholders of acquiring firms. Journal of Accounting Research 21, 184-221.

Shu, Z., 2000. Auditor resignations: Clientele effects and legal liability. Journal of Accounting and Economics 29(2): 173-205.

Skinner, D.J., Srinivasan, S., 2012. Audit quality and auditor reputation: Evidence from Japan. The Accounting Review, 87(5), 1737-1765.

Solomon, D., Gullapalli, D., 2005. SEC weighs a 'Big Three' world. The Wall Street Journal (Eastern edition). New York, N.Y.: June 22, 2005. p. C.1.

Thompson, R., Olsen, C., Dietrich, R.J., 1987. Attributes of news about firms: An analysis of firm-specific news reported in the Wall Street Journal Index. Journal of Accounting Research 25(2): 245-274.

United States Department of Justice, 2005. KPMG to pay \$456 million for criminal violations in relation to largest-ever tax shelter fraud case. Press Release, August 29, 2005. http://www.usdoj.gov/opa/pr/2005/August/05_ag_433.html.

United States Senate, 2003. Committee on Governmental Affairs, Permanent Subcommittee on Investigations. U.S. Tax Shelter Industry: The Role of Accountants, Lawyers and Financial Professionals. Report Prepared by the Minority Staff of the Permanent Subcommittee on Investigations Released in Conjunction with the Permanent Subcommittee on Investigations' Hearings on November 18 and 20, 2003.

Watkins, A. L., Hillison, W., Morecroft, S.E., 2004. Audit quality: A synthesis of theory and empirical evidence. Journal of Accounting Literature, 23, 153-193.

Weber, J., Willenborg, M., Zhang, J., 2008. Does auditor reputation matter? The case of KPMG Germany and ComROAD AG. Journal of Accounting Research, 46(4), 941-972.

Wilke, J. R., 2005. KPMG faces indictment risk on tax shelters; Justice officials debate whether to pursue case; Fears of 'Andersen scenario. The Wall Street Journal (Eastern edition). New York, N.Y.: June 16, 2005, pg. A.1. 
Willenborg, M., 1999. Empirical analysis of the economic demand for auditing in the initial public offerings market. Journal of Accounting Research, 37(1), 225-238.

Zmijewski, M., 1984. Methodological issues related to the estimation of financial distress prediction models. Journal of Accounting Research, 22(Supplement), 59-82. 
Table 1

Event dates in the tax shelter controversy timeline and brief description of the event

\begin{tabular}{|c|c|}
\hline Event dates & Brief description of the event \\
\hline June 26, 2002 & PwC announces settlement with the DOJ and the IRS. \\
\hline July 2, 2003 & EY announces settlement and fine with the IRS. \\
\hline November 18 and 20, 2003 & Congressional hearings on C-SPAN. \\
\hline January 12, 2004 & KPMG announces changes to high level tax personnel. \\
\hline February 20, 2004 & Federal grand jury investigation of KPMG announced. \\
\hline May 25, 2004 & $\begin{array}{l}\text { Criminal investigation of } \mathrm{EY} \text { tax shelter practices } \\
\text { announced. }\end{array}$ \\
\hline May 31,2005 & Supreme Court reverses Arthur Andersen conviction. \\
\hline June 16,2005 & KPMG addresses Department of Justice investigation. \\
\hline August 29, 2005 & $\begin{array}{l}\text { KPMG final } \$ 456 \text { million deferred settlement with the } \\
\text { Department of Justice and IRS announced; KPMG admits } \\
\text { to criminal wrongdoing. }\end{array}$ \\
\hline January 2007 & $\begin{array}{l}\text { KPMG completes payment requirements of deferred } \\
\text { settlement arrangement. }\end{array}$ \\
\hline May 7, 2007 & Some Ernst and Young tax partners indicted. \\
\hline May 31, 2007 & $\begin{array}{l}\text { Financial press reports EY, as a firm, likely will not be } \\
\text { charged. }\end{array}$ \\
\hline July 16, 2007 & $\begin{array}{l}\text { Judge dismisses charges against } 13 \text { of the } 16 \text { KPMG } \\
\text { partners charged in the tax case. }\end{array}$ \\
\hline May 8, 2009 & $\begin{array}{l}\text { Four EY partners found guilty by a jury in Manhattan on } \\
\text { all counts involving the sales of fraudulent tax shelters. }\end{array}$ \\
\hline March 1, 2013 & $\begin{array}{l}\text { EY announces settlement with the Manhattan U.S. } \\
\text { Attorney's office, with } \$ 123 \text { million in fines and penalties. }\end{array}$ \\
\hline
\end{tabular}


Table 2

\section{Selection of observations and descriptive statistics for the November 18, 2003 event date}

\section{Panel A: Determination of observations.}

Audit Analytics Universe

Less: firms with incomplete Compustat or CRSP data

firms which switched auditors

Final sample

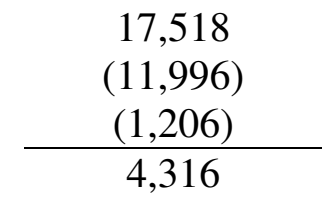

Panel B: Descriptive statistics of the final sample.

\begin{tabular}{|c|c|c|c|}
\hline $\begin{array}{l}\text { (\$ amounts in millions) } \\
\text { DT }(\mathrm{N}=744)\end{array}$ & Mean & Median & deviation \\
\hline Total assets & 8,772 & 707 & 44,726 \\
\hline Net sales & 3,108 & 469 & 11,789 \\
\hline Income before ext. items & 161 & 16 & 684 \\
\hline \multicolumn{4}{|l|}{$\mathrm{EY}(\mathrm{N}=1,028)$} \\
\hline Total assets & 5,476 & 552 & 39,600 \\
\hline Net sales & 2,228 & 345 & 10,445 \\
\hline Income before ext. items & 118 & 15 & 567 \\
\hline \multicolumn{4}{|l|}{ KPMG $(\mathrm{N}=806)$} \\
\hline Total assets & 5,281 & 528 & 51,730 \\
\hline Net sales & 1,842 & 237 & 9,382 \\
\hline Income before ext. items & 99 & 11 & 898 \\
\hline \multicolumn{4}{|l|}{ PwC (N=979) } \\
\hline Total assets & 9,531 & 676 & 57,159 \\
\hline Net sales & 3,169 & 412 & 12,424 \\
\hline Income before ext. items & 233 & 17 & 1,161 \\
\hline \multicolumn{4}{|l|}{$\operatorname{MIDSIZE}(\mathrm{N}=320)$} \\
\hline Total assets & 368 & 114 & 683 \\
\hline Net sales & 143 & 41 & 474 \\
\hline Income before ext. items & 6 & 2 & 52 \\
\hline \multicolumn{4}{|l|}{ SMALL $(\mathrm{N}=439)$} \\
\hline Total assets & 309 & 77 & 775 \\
\hline Net sales & 50 & 23 & 97 \\
\hline Income before ext. items & 2 & 1 & 10 \\
\hline
\end{tabular}

DT is Deloitte Touche, LLP; EY is Ernst \& Young, LLP; KPMG is KPMG, LLP; PwC is PricewaterhouseCoopers, LLP; Midsize is the group of auditing firm including Grant Thornton, LLP; BDO Seidman, LLP; Crowe Chizak, LLP; McGladrey and Pullen, LLP and Plante and Moran, LLP, and Small consists of all other CPA firms. Total assets and Net sales are from each sample firm's latest audited financial statements prior to the event date reported in Compustat. Income before ext. items is Income before extraordinary items reported on the latest audited income statement prior to the event date reported in Compustat. 
Table 3

Mean and median cumulative abnormal returns of audit clients when criminal investigations of large CPA firms were announced

\begin{tabular}{|c|c|c|c|c|c|c|}
\hline $\begin{array}{r}\text { Auditor } \\
\text { group }\end{array}$ & $N$ & Pos/Neg & $\begin{array}{r}\text { Mean } \\
\text { CAR } \\
\end{array}$ & $\begin{array}{r}\text { Median } \\
C A R\end{array}$ & $\begin{array}{r}\text { Mean t-test } \\
\text { Patell Z } \\
\end{array}$ & $\begin{array}{c}\text { Generalized } \\
\text { Sign test } Z \\
\end{array}$ \\
\hline DT & 755 & $304: 451$ & $-0.71 \%$ & $-0.51 \%$ & $-3.833 * * *$ & $-3.967 * * *$ \\
\hline $\mathrm{EY}$ & 1,033 & $350: 683$ & $-1.60 \%$ & $-1.15 \%$ & $-9.007 * * *$ & $-8.704 * * *$ \\
\hline KPMG & 807 & $331: 476$ & $-1.07 \%$ & $-0.77 \%$ & $-4.535 * * *$ & $-3.468 * * *$ \\
\hline PwC & 1,001 & 404:597 & $-1.19 \%$ & $-0.72 \%$ & $-7.314 * * *$ & $-4.742 * * *$ \\
\hline Midsize & 319 & $121: 198$ & $-1.82 \%$ & $-0.88 \%$ & $-4.839 * * *$ & $-2.636 * *$ \\
\hline Small & 445 & $174: 271$ & $-1.73 \%$ & $-0.77 \%$ & $-4.882 * * *$ & $-2.312 *$ \\
\hline
\end{tabular}

Panel B: May 25, 2004, announcement EY was under a criminal investigation.

\begin{tabular}{|c|c|c|c|c|c|c|}
\hline $\begin{array}{r}\text { Auditor } \\
\text { group }\end{array}$ & $N$ & Pos/Neg & $\begin{array}{r}\text { Mean } \\
\text { CAR }\end{array}$ & $\begin{array}{r}\text { Median } \\
\text { CAR } \\
\end{array}$ & $\begin{array}{r}\text { Mean t-test } \\
\text { Patell Z } \\
\end{array}$ & $\begin{array}{r}\text { Generalized } \\
\text { Sign test Z }\end{array}$ \\
\hline DT & 769 & 402:367 & $0.20 \%$ & $0.17 \%$ & $3.814 * * *$ & $2.827 * *$ \\
\hline EY & 1,056 & 523:533 & $-0.06 \%$ & $-0.02 \%$ & $3.120 * * *$ & $1.516 \$$ \\
\hline KPMG & 816 & 397:419 & $-0.10 \%$ & $-0.11 \%$ & $1.535 \$$ & 1.029 \\
\hline PwC & 1,016 & 539:477 & $0.03 \%$ & $0.20 \%$ & $3.858 * * *$ & $3.550 * * *$ \\
\hline Midsize & 421 & $166: 255$ & $-0.54 \%$ & $-0.91 \%$ & $-1.898 *$ & $-2.449 * *$ \\
\hline Small & 552 & 213:339 & $-0.38 \%$ & $-0.81 \%$ & $-2.033 *$ & $-2.697 * *$ \\
\hline
\end{tabular}

$* * *, * *, *, \$$ Significant at the $0.001,0.01,0.05$, and 0.10 percent level, respectively, using a one-tailed test.

Pos/Neg is ratio of number of positive to negative CAR for publicly listed audit clients of the respective auditor group on the date indicated.

Mean CAR is mean cumulative abnormal returns using sizeindx = own market option to determine CAR, matching each stock in the sample to the market and a size decile using the CRSP reported exchange and decile number as of the event date. Eventus is used to calculate the 3-day cumulative abnormal returns ( $t=$ -1 to +1 ) using the market model and the NYSE-only, AMEX-only, and NASDAQ-only size-decile portfolios as replacement market indices for NYSE, AMEX, and NASDAQ stocks, respectively.

Median CAR is the median cumulative abnormal returns.

Mean t-test Patell $\mathbf{Z}$ is the standard Patell (1976) test assuming independent and identical distributions of abnormal returns.

Generalized Sign test $\mathbf{Z}$ is the Cowan (1992) generalized sign test indicating whether the proportion of positive to negative abnormal returns around the event date is the same as in the estimation period. 
Table 4

Mean and median cumulative abnormal returns of audit clients of CPA firms:

November 18, 2003, the Congressional hearing on tax shelters

\begin{tabular}{|c|c|c|c|c|c|c|}
\hline $\begin{array}{c}\text { Auditor } \\
\text { group }\end{array}$ & $N$ & Pos/Neg & $\begin{array}{r}\text { Mean } \\
\text { CAR }\end{array}$ & $\begin{array}{r}\text { Median } \\
C A R\end{array}$ & $\begin{array}{r}\text { Mean } t- \\
\text { test } \\
\text { Patell Z }\end{array}$ & $\begin{array}{r}\text { Generalized } \\
\text { Sign test } Z\end{array}$ \\
\hline DT & 744 & $337 / 407$ & $-0.47 \%$ & $-0.29 \%$ & $-1.660 *$ & $-1.406 \$$ \\
\hline EY & 1,028 & $455: 573$ & $-0.54 \%$ & $-0.45 \%$ & $-1.551 \$$ & $-2.240 *$ \\
\hline KPMG & 806 & $361: 445$ & $-0.40 \%$ & $-0.31 \%$ & $-1.349 \$$ & $-1.528 \$$ \\
\hline PwC & 979 & $416: 563$ & $-0.51 \%$ & $-0.32 \%$ & $-3.398 * * *$ & $-3.537 * * *$ \\
\hline Midsize & 320 & $137: 183$ & $-0.98 \%$ & $-0.45 \%$ & $-1.712 *$ & -1.007 \\
\hline Small & 439 & $169: 270$ & $-0.96 \%$ & $-0.60 \%$ & $-1.721 *$ & $-2.566 * *$ \\
\hline
\end{tabular}


Table 5

Mean and median cumulative abnormal returns of KPMG audit clients on tax shelter event dates

\begin{tabular}{|c|c|c|c|c|c|c|}
\hline $\begin{array}{c}\text { KPMG event dates } \\
\text { (see Table } 1 \text { for a } \\
\text { description of each } \\
\text { event date) }\end{array}$ & $N$ & Pos/Neg & $\begin{array}{r}\text { Mean } \\
\text { CAR } \\
\end{array}$ & $\begin{array}{r}\text { Median } \\
\text { CAR } \\
\end{array}$ & $\begin{array}{r}\text { Mean t-test } \\
\text { Patell Z } \\
\end{array}$ & $\begin{array}{r}\text { Generalized } \\
\text { Sign test Z } \\
\end{array}$ \\
\hline November 18, 2003 & 806 & $361: 445$ & $-0.40 \%$ & $-0.31 \%$ & $-1.349 \$$ & $-1.528 \$$ \\
\hline January 12, 2004 & 803 & 411:392 & $0.56 \%$ & $0.08 \%$ & $1.814^{*}$ & $2.278 *$ \\
\hline February 20, 2004 & 807 & $331: 476$ & $-1.07 \%$ & $-0.77 \%$ & $-4.535 * * *$ & $-3.468 * * *$ \\
\hline May 31, 2005 & 838 & 390:448 & $0.04 \%$ & $-0.21 \%$ & 0.683 & -0.987 \\
\hline June 16, 2005 & 840 & $392: 448$ & $0.21 \%$ & $-0.18 \%$ & 0.338 & -0.973 \\
\hline August 29, 2005 & 840 & $381: 459$ & $-0.16 \%$ & $-0.27 \%$ & $-3.001 * *$ & $-1.581 \$$ \\
\hline
\end{tabular}


Table 6

Market reaction to publicized events of tax shelter activities on the audit market ${ }^{29}$

\begin{tabular}{|c|c|c|c|c|c|c|}
\hline \multirow{2}{*}{\multicolumn{7}{|c|}{ Schipper and Thompson (1983) regression model: $R_{p, t}=\alpha+\beta R_{m, t}+\sum \delta_{k}$ Event $_{k, t}+\varepsilon_{t}$}} \\
\hline & & & & & & Panel A: Federal Grand Jury Investigation of KPMG: 02/20/2004 \\
\hline & KPMG & EY & $\mathrm{PwC}$ & DT & Midsize & Small \\
\hline Variables & $\begin{array}{l}\text { Coefficient } \\
\text { (t-statistic) }\end{array}$ & $\begin{array}{l}\text { Coefficient } \\
\text { (t-statistic) }\end{array}$ & $\begin{array}{l}\text { Coefficient } \\
\text { (t-statistic) }\end{array}$ & $\begin{array}{l}\text { Coefficient } \\
\text { (t-statistic) }\end{array}$ & $\begin{array}{l}\text { Coefficient } \\
\text { (t-statistic) }\end{array}$ & $\begin{array}{l}\text { Coefficient } \\
\text { (t-statistic) }\end{array}$ \\
\hline Constant & $\begin{array}{l}0.001 \\
(4.42)^{*} * *\end{array}$ & $\begin{array}{l}0.001 \\
(3.37) * * *\end{array}$ & $\begin{array}{l}0.001 \\
(3.49) * * *\end{array}$ & $\begin{array}{l}0.001 \\
(4.27) * * *\end{array}$ & $\begin{array}{l}0.001 \\
(5.55)^{* * * *}\end{array}$ & $\begin{array}{l}0.001 \\
(6.35)^{* * *}\end{array}$ \\
\hline$R_{m}$ & $\begin{array}{l}1.004 \\
(36.52) * * *\end{array}$ & $\begin{array}{l}1.068 \\
(37.24) * * *\end{array}$ & $\begin{array}{l}1.068 \\
(41.20)^{* * * *}\end{array}$ & $\begin{array}{l}0.937 \\
(39.60) * * *\end{array}$ & $\begin{array}{l}0.615 \\
(20.14) * * *\end{array}$ & $\begin{array}{l}0.490 \\
(15.26)^{* * *}\end{array}$ \\
\hline Event & $\begin{array}{l}-0.004 \\
(-1.79) *\end{array}$ & $\begin{array}{l}-0.007 \\
(-2.57) * *\end{array}$ & $\begin{array}{l}-0.005 \\
(-2.12)^{* *}\end{array}$ & $\begin{array}{l}-0.003 \\
(-1.54)\end{array}$ & $\begin{array}{l}-0.008 \\
(-2.97) * * *\end{array}$ & $\begin{array}{l}-0.006 \\
(-2.20)^{* *}\end{array}$ \\
\hline Adj. $R^{2}$ & 0.832 & 0.838 & 0.863 & 0.853 & 0.607 & 0.469 \\
\hline \multicolumn{7}{|c|}{ Panel B: Criminal Investigation of EY: 05/25/2004 } \\
\hline & KPMG & EY & $\mathrm{PwC}$ & DT & Mid-Tier & Small-Tier \\
\hline Variables & $\begin{array}{l}\text { Coefficient } \\
\text { (t-statistic) }\end{array}$ & $\begin{array}{l}\text { Coefficient } \\
\text { (t-statistic) }\end{array}$ & $\begin{array}{l}\text { Coefficient } \\
\text { (t-statistic) }\end{array}$ & $\begin{array}{l}\text { Coefficient } \\
\text { (t-statistic) }\end{array}$ & $\begin{array}{l}\text { Coefficient } \\
\text { (t-statistic) }\end{array}$ & $\begin{array}{l}\text { Coefficient } \\
\text { (t-statistic) }\end{array}$ \\
\hline Constant & $\begin{array}{l}0.001 \\
(4.19) * * *\end{array}$ & $\begin{array}{l}0.001 \\
(3.01)^{* * * *}\end{array}$ & $\begin{array}{l}0.001 \\
(3.20) * * *\end{array}$ & $\begin{array}{l}0.001 \\
(4.27) * * *\end{array}$ & $\begin{array}{l}0.001 \\
(5.22) * * *\end{array}$ & $\begin{array}{l}0.002 \\
(6.14) * * *\end{array}$ \\
\hline$R_{m}$ & $\begin{array}{l}1.006 \\
(36.26)^{* * * *}\end{array}$ & $\begin{array}{l}1.070 \\
(36.76)^{* * *}\end{array}$ & $\begin{array}{l}1.070 \\
(40.80)^{* * *}\end{array}$ & $\begin{array}{l}0.937 \\
(39.60) * * *\end{array}$ & $\begin{array}{l}0.621 \\
(19.96)^{* * * *}\end{array}$ & $\begin{array}{l}0.495 \\
(15.25)^{* * *}\end{array}$ \\
\hline Event & $\begin{array}{l}0.000 \\
(0.20)\end{array}$ & $\begin{array}{l}0.001 \\
(0.58)\end{array}$ & $\begin{array}{l}0.001 \\
(0.49)\end{array}$ & $\begin{array}{l}-0.003 \\
(-1.54)\end{array}$ & $\begin{array}{l}-0.001 \\
(-0.37)\end{array}$ & $\begin{array}{l}-0.001 \\
(-0.49)\end{array}$ \\
\hline $\operatorname{Adj} . R^{2}$ & 0.830 & 0.834 & 0.861 & 0.853 & 0.595 & 0.460 \\
\hline \multicolumn{7}{|c|}{ Panel C: Congressional Hearing Date: $11 / 18 / 2003$} \\
\hline & KPMG & EY & $\mathrm{PwC}$ & DT & Mid-Tier & Small-Tier \\
\hline Variables & $\begin{array}{l}\text { Coefficient } \\
\text { (t-statistic) }\end{array}$ & $\begin{array}{l}\text { Coefficient } \\
\text { (t-statistic) }\end{array}$ & $\begin{array}{l}\text { Coefficient } \\
\text { (t-statistic) }\end{array}$ & $\begin{array}{l}\text { Coefficient } \\
\text { (t-statistic) }\end{array}$ & $\begin{array}{l}\text { Coefficient } \\
\text { (t-statistic) }\end{array}$ & $\begin{array}{l}\text { Coefficient } \\
\text { (t-statistic) }\end{array}$ \\
\hline Constant & $\begin{array}{l}0.001 \\
(6.31)^{* * * *}\end{array}$ & $\begin{array}{l}0.001 \\
(5.86) * * *\end{array}$ & $\begin{array}{l}0.001 \\
(5.81) * * *\end{array}$ & $\begin{array}{l}0.001 \\
(6.46) * * *\end{array}$ & $\begin{array}{l}0.002 \\
(9.11)^{* * * *}\end{array}$ & $\begin{array}{l}0.003 \\
(11.15)^{* * * *}\end{array}$ \\
\hline$R_{m}$ & $\begin{array}{l}0.765 \\
(33.69) * * *\end{array}$ & $\begin{array}{l}0.845 \\
(35.46) * * *\end{array}$ & $\begin{array}{l}0.841 \\
(39.00) * * *\end{array}$ & $\begin{array}{l}0.729 \\
(37.44) * * *\end{array}$ & $\begin{array}{l}0.387 \\
(16.50) * * *\end{array}$ & $\begin{array}{l}0.024 \\
(11.45)^{* * *}\end{array}$ \\
\hline Event & $\begin{array}{l}-0.003 \\
(-1.60)\end{array}$ & $\begin{array}{l}-0.003 \\
(-1.61)\end{array}$ & $\begin{array}{l}-0.002 \\
(-1.36)\end{array}$ & $\begin{array}{l}-0.002 \\
(-1.66)\end{array}$ & $\begin{array}{l}-0.004 \\
(-2.38)^{* *}\end{array}$ & $\begin{array}{l}-0.005 \\
(-2.76) * * *\end{array}$ \\
\hline $\operatorname{Adj} . R^{2}$ & 0.821 & 0.836 & 0.860 & 0.850 & 0.531 & 0.363 \\
\hline $\begin{array}{l}* * *, * *, *, \\
\text { Coefficient } \\
\text { mean exces } \\
\text { equals one } \\
\text { return to an } \\
\text { weighted da }\end{array}$ & Significant at & $0.001,0.01$, & 5 , and $0.10 \mathrm{p}$ & ent level, re & tively, (two & $\begin{array}{l}\text { ed test). } \\
\text { the "shift in } \\
\text { 196). Event } \\
\text { uals the daily }\end{array}$ \\
\hline
\end{tabular}

${ }^{29}$ The estimation periods are as follows: Panels A and B: June 1, 2003 - June 30, 2004; Panel C: January 1, 2003 - December 31, 2003. 
Table 7

Regression of 3-day CARs on proxies for auditor reputation and insurance of audit clients of KPMG, EY, and PwC on November 18, 2003

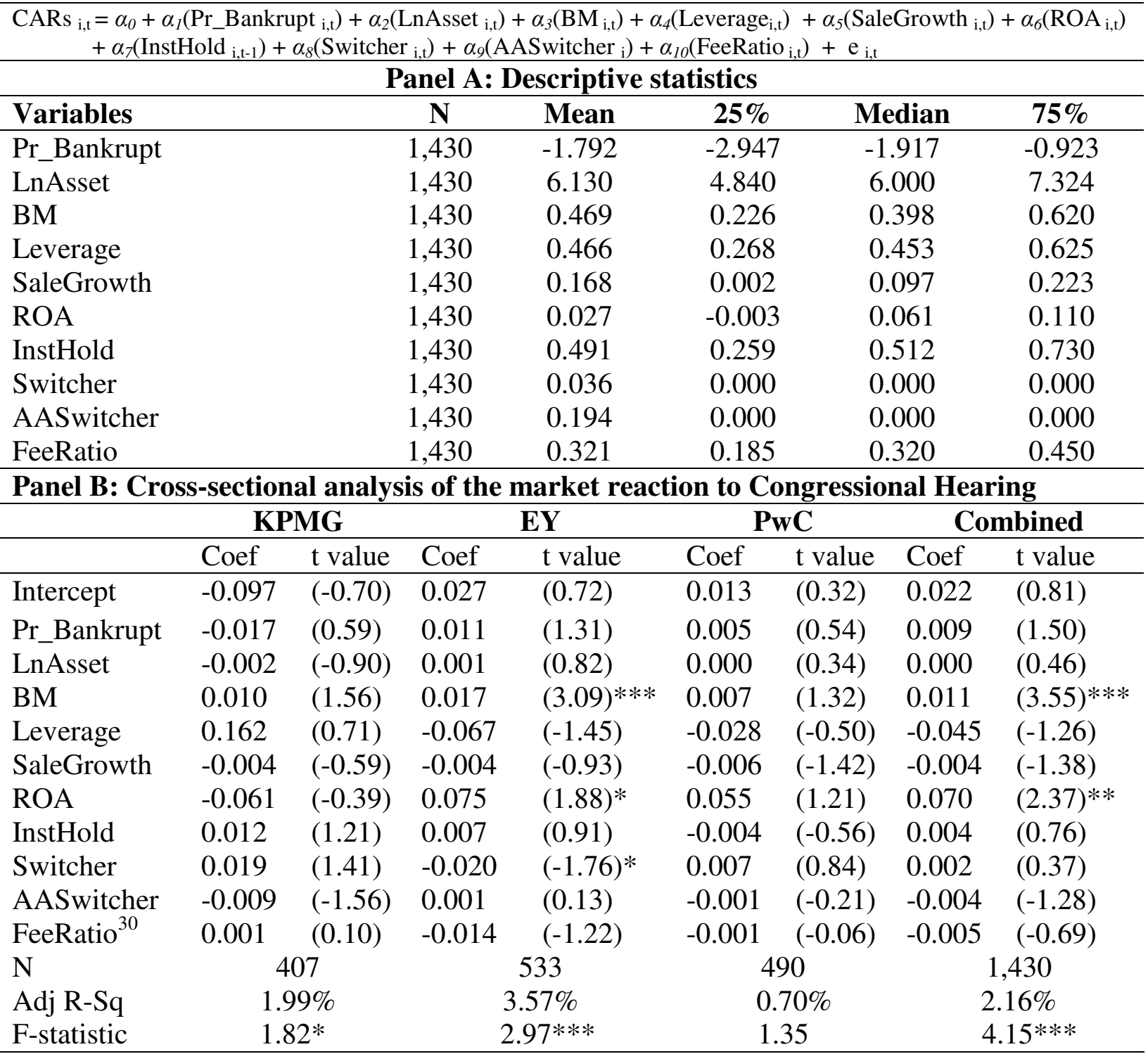

***,**,* Significant at the $0.01,0.05$, and 0.10 percent level, respectively, using a two-tailed test.

Pr_Bankrupt is the Zmijewski (1984) financial distress measure; LnAsset is the natural log of total assets, in millions; $B M$ is the book value of equity divided by the market value of equity; Leverage is the ratio of total debt to total assets; SaleGrowth is the growth rate in sales; ROA is the return on assets; InstHold is the $\%$ of shares owned by institutional shareholders; Switcher is 1 if firm i switches auditors in year t or t-1,0 otherwise; AASwitcher is 1 if firm i switched from Arthur Andersen in years 2000-2003, and 0 otherwise; FeeRatio is the ratio of non-audit fees to total fees. Note the number of observations in this Table $7(\mathrm{~N}=$ 1,430 ) is less than the total number of observations in Tables 2 and 4 for KPMG, EY, and PwC, combined $(\mathrm{N}=2,813)$ due to missing firm observations for the variables included in the Table 7 model. 


\section{Table 8}

Cross-sectional analysis of the market reaction of KPMG audit clients to the February 20, 2004 announcement of the Federal Grand Jury investigation of KPMG

\begin{tabular}{|c|c|c|}
\hline \multicolumn{3}{|c|}{ 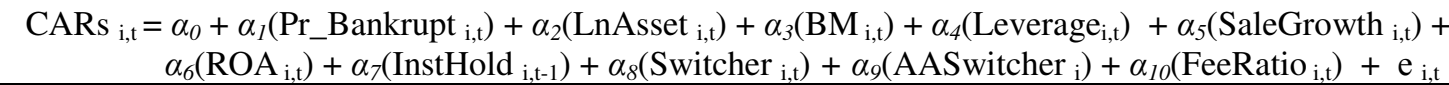 } \\
\hline & Coefficient & $\mathrm{t}$ value \\
\hline Intercept & -0.309 & $(-2.30) * *$ \\
\hline Pr_Bankrupt & -0.065 & $(-2.05)^{*}$ \\
\hline LnAsset & -0.005 & $(-2.09) * *$ \\
\hline $\mathrm{BM}$ & 0.023 & $(2.81)^{* * *}$ \\
\hline Leverage & 0.429 & $(2.38) * *$ \\
\hline SaleGrowth & -0.003 & $(-0.44)$ \\
\hline ROA & -0.263 & $(-1.80)^{*}$ \\
\hline InstHold & 0.001 & $(0.12)$ \\
\hline Switcher & 0.016 & $(0.97)$ \\
\hline AASwitcher & 0.005 & $(0.72)$ \\
\hline FeeRatio & 0.009 & $(0.54)$ \\
\hline $\mathrm{N}$ & 403 & \\
\hline Adj R-Sq & $5.70 \%$ & \\
\hline F-statistic & $3.43 * * *$ & \\
\hline
\end{tabular}

***,**,* Significant at the $0.01,0.05$, and 0.10 percent level, respectively, using a two-tailed test.

Note the number of observations in this Table $(\mathrm{N}=403)$ is less than the number of observations in Table 5 $(\mathrm{N}=807)$ for KPMG due to missing firm observations for the variables included in the Table 8 model. 